Andreas Paul, Elmar Baumhögger, Andreas Elsner, Lukas Moczarski, Michael Reineke, Gerrit Sonnenrein, Christian Hueppe, Rainer Stamminger, Heike Hoelscher, Hendrik Wagner, Ulrich Gries, Alfred Freiberger, Wolfgang Becker, Jadran Vrabec

\title{
Determining the heat flow through the cabinet walls of household refrigerating appliances
}

Journal article | Accepted manuscript (Postprint)

This version is available at https://doi.org/10.14279/depositonce-10925

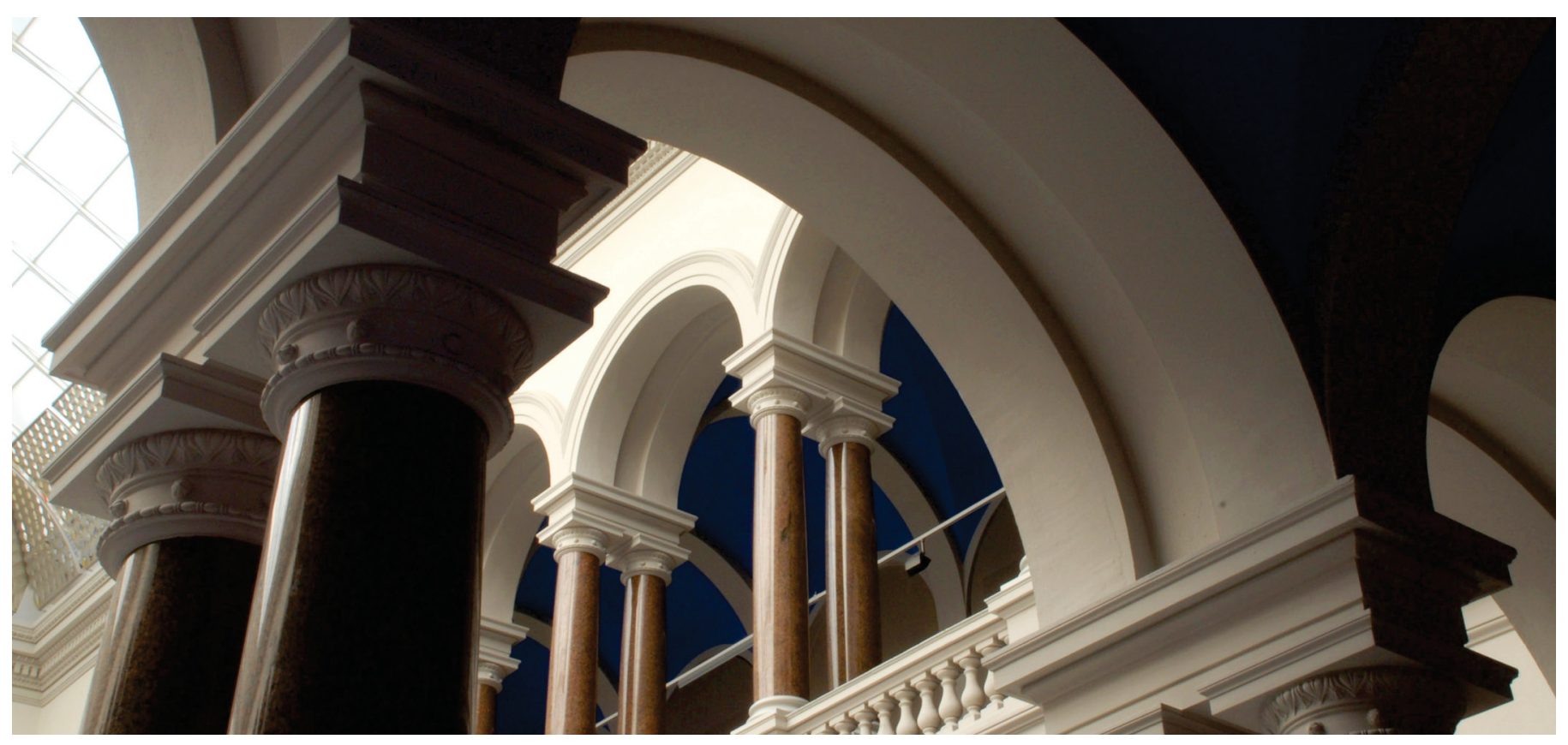

Paul, A., Baumhoegger, E., Elsner, A., Moczarski, L., Reineke, M., Sonnenrein, G., Hueppe, C.,

Stamminger, R., Hoelscher, H., Wagner, H., Gries, U., Freiberger, A., Becker, W., \& Vrabec, J. (2020).

Determining the heat flow through the cabinet walls of household refrigerating appliances. International

Journal of Refrigeration. https://doi.org/10.1016/j.ijrefrig.2020.10.007 


\title{
Determining the heat flow through the cabinet walls of household refrigerating appliances
}

\begin{abstract}
Andreas Paul ${ }^{a}, \mathbf{b}$, Elmar Baumhögger ${ }^{a}$, Andreas Elsner ${ }^{a}$, Lukas Moczarski ${ }^{a}, \mathbf{b}$, Michael Reineke ${ }^{a}$, Gerrit Sonnenrein ${ }^{\text {a }}$, Christian Hueppe ${ }^{c}$, Rainer Stamminger c, Heike Hoelscher $^{d}$, Hendrik Wagner ${ }^{d}$, Ulrich Gries ${ }^{e}, \quad$ Alfred Freiberger ${ }^{f}$, Wolfgang Becker ${ }^{g}$, Jadran Vrabec ${ }^{b}$ *
\end{abstract}

a Thermodynamics and Energy Technology, University of Paderborn, Warburger Str. 100, 33098 Paderborn, Germany

b Thermodynamics and Process Engineering, Technical University of Berlin, Ernst-Reuter-Platz 1, 10587 Berlin, Germany

c Institute of Agricultural Engineering - Section Household and Appliance Engineering, University of Bonn, Nussallee 5, 53115 Bonn, Germany

d BASF Polyurethanes GmbH, Elastogranstraße 60, 49448 Lemförde, Germany

e Secop GmbH, Mads-Clausen-Str. 7, 24939 Flensburg, Germany

f Secop Austria GmbH, Jahnstraße 30, 8280 Fürstenfeld, Austria

g BSH Home Appliances GmbH, Robert-Bosch-Straße 100, 89537 Giengen an der Brenz, Germany

* corresponding author

\section{Highlights}

- A measurement method for determining the $k \cdot A$ value of household refrigerating appliances is presented.

- A latent heat sink is a suitable alternative to the reverse heat leak method.

- Air flow and storage temperatures in the refrigerator compartment are comparable to the real operating conditions.

- Temperature gradients between the storage room and the ambient of the refrigerating appliances are more realistic.

- An age-related increase of the $k \cdot A$ value of between $3.6 \%$ and $11.5 \%$ is found over a period of 14 months.

\section{Keywords}

Household refrigerating appliances, PUR foam, $k \cdot A$ value, Insulation, Measurement method

Accepted manuscript of: Paul, A., Baumhoegger, E., Elsner, A., Moczarski, L., Reineke, M., Sonnenrein, G., Hueppe, C., Stamminger, R., Hoelscher, H., Wagner, H., Gries, U., Freiberger, A., Becker, W., \& Vrabec, J. (2020). Determining the heat flow through the cabinet walls of household refrigerating appliances.

International Journal of Refrigeration. https://doi.org/10.1016/j.ijrefrig.2020.10.007

(C) 2020 This manuscript version is made available under the CC-BY-NC-ND 4.0 license

https://creativecommons.org/licenses/by-nc-nd/4.0/ 


\begin{abstract}
The increase of the thermal conductivity of PUR foam in the insulation of the cabinet is an important cause for aging processes of household refrigerating appliances. To determine the influence of the PUR foam aging on energy consumption, the development of a new measurement method is necessary because current methods influence the aging behavior of household refrigerators and are therefore not applicable in general. Based on a latent heat sink, constructed as an ice water bucket, a new measurement method is developed to determine the $k \cdot A$ value over time. With this method, the $k \cdot A$ value of four household refrigerating appliances was determined over an interval of 14 months. The $k \cdot A$ value increased between $3.6 \%$ and $11.5 \%$ during this period.
\end{abstract}




\section{Nomenclature}

\begin{tabular}{|c|c|}
\hline$A$ & Surface $\left(m^{2}\right)$ \\
\hline$A_{a}$ & Outer surface $\left(\mathrm{m}^{2}\right)$ \\
\hline$A_{i}$ & Inner surface $\left(\mathrm{m}^{2}\right)$ \\
\hline$A_{j}$ & Average surface of material layer $\mathrm{j}\left(\mathrm{m}^{2}\right)$ \\
\hline$c_{v, \text { ice }}$ & Specific isochoric heat capacity of ice $(\mathrm{kJ} /(\mathrm{kg} \mathrm{K})$ \\
\hline$d_{j}$ & Material thickness of layer $j(\mathrm{~mm})$ \\
\hline$k$ & Heat transfer coefficient $\left(\mathrm{W} /\left(\mathrm{m}^{2} \mathrm{~K}\right)\right)$ \\
\hline$(k \cdot A)_{\text {total }}$ & $k \cdot A$ value related to the ice water bucket $(\mathrm{W} / \mathrm{K})$ \\
\hline$(k \cdot A)_{f f c}$ & $k \cdot A$ value related to the fresh food compartment $(\mathrm{W} / \mathrm{K})$ \\
\hline$m_{\text {ice }}$ & Mass of ice of the second addition $(\mathrm{kg})$ \\
\hline$P_{\text {pump }}$ & Power of pump (W) \\
\hline$\dot{Q}_{i c e}$ & Heat flow absorbed by the ice (W) \\
\hline$\dot{Q}_{c a b}$ & Heat flow through the cabinet (W) \\
\hline$\dot{Q}_{\text {total }}$ & Heat flow related to the ice water bucket $(\mathrm{W})$ \\
\hline$\dot{Q}_{f f c}$ & Heat flow related to the fresh food compartment (W) \\
\hline$T_{a}$ & Ambient temperature $\left({ }^{\circ} \mathrm{C}\right)$ \\
\hline$T_{i c e}$ & Time averaged ice temperature $\left({ }^{\circ} \mathrm{C}\right)$ \\
\hline$T_{i c e, i}$ & Instantaneous ice temperature $\left({ }^{\circ} \mathrm{C}\right)$ \\
\hline$T_{i c e, 1}$ & Storage temperature of the ice $\left({ }^{\circ} \mathrm{C}\right)$ \\
\hline$T_{i}$ & Temperature inside $\left({ }^{\circ} \mathrm{C}\right)$ \\
\hline$T_{m a}$ & Time averaged temperature of heat sink measurements $\left({ }^{\circ} \mathrm{C}\right)$ \\
\hline$T_{1}$ & Temperature at measurement point $1\left({ }^{\circ} \mathrm{C}\right)$ \\
\hline$T_{2}$ & Temperature at measurement point $2\left({ }^{\circ} \mathrm{C}\right)$ \\
\hline$T_{3}$ & Temperature at measurement point $3\left({ }^{\circ} \mathrm{C}\right)$ \\
\hline$\alpha_{a}$ & Heat transfer coefficient outside $\left(\mathrm{W} /\left(\mathrm{m}^{2} \mathrm{~K}\right)\right)$ \\
\hline$\alpha_{i}$ & Heat transfer coefficient inside $\left(\mathrm{W} /\left(\mathrm{m}^{2} \mathrm{~K}\right)\right)$ \\
\hline$\Delta h_{m}$ & Enthalpy of fusion of ice $(\mathrm{kJ} / \mathrm{kg})$ \\
\hline$\Delta(k \cdot A)_{\text {total }}$ & Measurement error related to the ice water bucket (\%) \\
\hline$\Delta(k \cdot A)_{f f c}$ & Measurement error related to the fresh food compartment (\%) \\
\hline$\Delta(k \cdot A)_{\max }$ & Maximum measurement error (\%) \\
\hline$\Delta \tau_{m}$ & Melting time (s) \\
\hline$\Delta T$ & Temperature difference (K) \\
\hline$\lambda_{j}$ & Thermal conductivity of material layer $(\mathrm{W} /(\mathrm{m} \mathrm{K}))$ \\
\hline$\lambda_{P S}$ & Thermal conductivity of HIPS (W/(m K)) \\
\hline$\lambda_{P U R}$ & Thermal conductivity of PUR foam (W/(m K)) \\
\hline$\lambda_{S T}$ & Thermal conductivity of steel $(\mathrm{W} /(\mathrm{m} \mathrm{K}))$ \\
\hline
\end{tabular}




\section{$1 \quad$ Introduction}

Due to the increasing customer awareness of global warming and the necessary reduction of greenhouse gas emissions, the EU energy label has become an essential selling point for modern household refrigerating appliances [1]. It compares household refrigerating appliances with respect to their energy consumption, storage volume as well as construction type and classifies them according to their energy efficiency. For this purpose, standardized measuring methods are used to sample these quantities of new household refrigerating appliances. However, like any technical system, household refrigerating appliances are subject to considerable technical degeneration over their lifespan of up to 20 years in some cases. An Australian study from 1990 on household refrigerating appliances, most likely with CFC-containing PUR foams, showed no aging influence on energy consumption in the first two years [2]. Typically, CFC-11 was used in PUR foams at the time when that study was carried out [3-5]. First prototypes of CFC-free household refrigerating appliances were developed in 1992 [6]. Around 1994, the first models of this appliance type were brought into the market in significant numbers [7,8]. Due to a low water content in the raw materials, CFC-containing PUR foams are typically less susceptible to aging processes than current state-of-the-art cyclopentane-blown PUR foams [9]. Elsner et al. showed an increase of energy consumption between $20 \%$ and $35 \%$ over a period of 18 years for household refrigerating appliances with PUR foams that do not contain CFC [10]. Harrington examined the influence of the energy saving potential by replacing old appliances through modern appliances [11]. The study showed that the replacement of older appliances has an energy saving potential of about $60 \%$. In his dissertation [12], Harrington examined the influence of consumer behavior on energy consumption of household refrigerating appliances. Among others, he determined the influence of temperature and humidity in the storage room, ambient temperature, evaporator defrosting, door openings and the general choice of the model. Wagner developed methods to simulate heat transfer through PUR foam as a part of his dissertation [13].

The method described in this paper is part of a larger project that aims to determine the energy consumption increase of new household refrigerators over a period of three years with non-destructive measurement methods.

\subsection{Aging of PUR foams}

With a share of $45 \%$ to $55 \%$, the heat flow entering the storage room through the cabinet represents the largest driver for the energy consumption of a household refrigerating appliance [14]. The cabinet essentially consists of an approximately $1 \mathrm{~mm}$ layer of galvanized sheet steel on the outside, a 40-60 mm thick core made of PUR foam and an approximately 0.6-2 mm layer of high impact polystyrene (HIPS) on the inside towards the storage room. During the manufacturing process, isocyanates and polyols react in a polyaddition reaction to PUR. A second blowing reaction between isocyanates and water leads to $\mathrm{CO}_{2}$-formation. The $\mathrm{CO}_{2}$ and the additional physical blowing agent cyclopentane (isopentane) cause foam rise of the PUR. After the manufacturing process, the cell gas of the PUR foam primarily consists of $\mathrm{CO}_{2}$ and cyclopentane. Through diffusion processes, $\mathrm{CO}_{2}$ is replaced over time by nitrogen and oxygen from the ambient air $[9,15-17]$. This leads to an increase of the thermal conductivity of the PUR foam $\left(\lambda_{P U R}\right)$ and thus to an increase of the energy consumption of household refrigerating appliances [18-23]. This process is strongly dependent on 
the temperature that the PUR foam is exposed to [18-22]. Current research projects are examining the replacement of the blowing agent pentane with $\mathrm{CO}_{2}$-water mixtures. However, this would not prevent aging due to diffusion processes, since $\mathrm{CO}_{2}$ is also present in these PUR foam cells as a reaction product [17]. Instead, the aging problem would be exacerbated with a $\mathrm{CO}_{2}$-water mixture as a blowing agent.

\subsection{Heat transfer through the cabinet walls}

The heat flow through the cabinet walls $\left(\dot{Q}_{c a b}.\right)$ can be expressed as a product of the heat transfer coefficient $(k)$, the surface area over which the heat transfer takes place $(A)$ and the temperature difference $(\Delta T)$ between the ambient $\left(T_{a}\right)$ and the temperature inside the cabinet $\left(T_{i}\right)$ of the household refrigerating appliance.

$$
\dot{Q}_{C a b .}=k \cdot A \cdot \Delta T=k \cdot A \cdot\left(T_{a}-T_{i}\right)
$$

The heat transfer coefficient $k$ is constituted by the convective heat transfer coefficients on the outside $\left(\alpha_{a}\right)$ and inside $\left(\alpha_{i}\right)$ surface of the cabinet, the material thicknesses of the various layers of the wall structure $\left(d_{j}\right)$ and the thermal conductivity of the materials $\left(\lambda_{j}\right)$. Equation 2 also considers the typically different surface sizes of the outside $\left(A_{a}\right)$ and inside $\left(A_{i}\right)$ of the cabinet and the middle surfaces of the different material layers $\left(A_{j}\right)$.

$$
\frac{1}{k \cdot A}=\frac{1}{\alpha_{a} \cdot A_{a}}+\sum_{j=1}^{n} \frac{d_{j}}{\lambda_{j} \cdot A_{j}}+\frac{1}{\alpha_{i} \cdot A_{i}}
$$

A schematic of the cabinet walls and the resulting temperature profile is shown in Figure 1. With increasing usage time, the thermal conductivity of the PUR foam $\left(\lambda_{P U R}\right)$ increases, while the thermal conductivity of the galvanized steel sheet $\left(\lambda_{S T}\right)$ on the outside and that of the HIPS inliner $\left(\lambda_{P S}\right)$ remain constant. Consequently, the heat flow entering the cabinet increases and so does the energy consumption of the refrigeration process. 


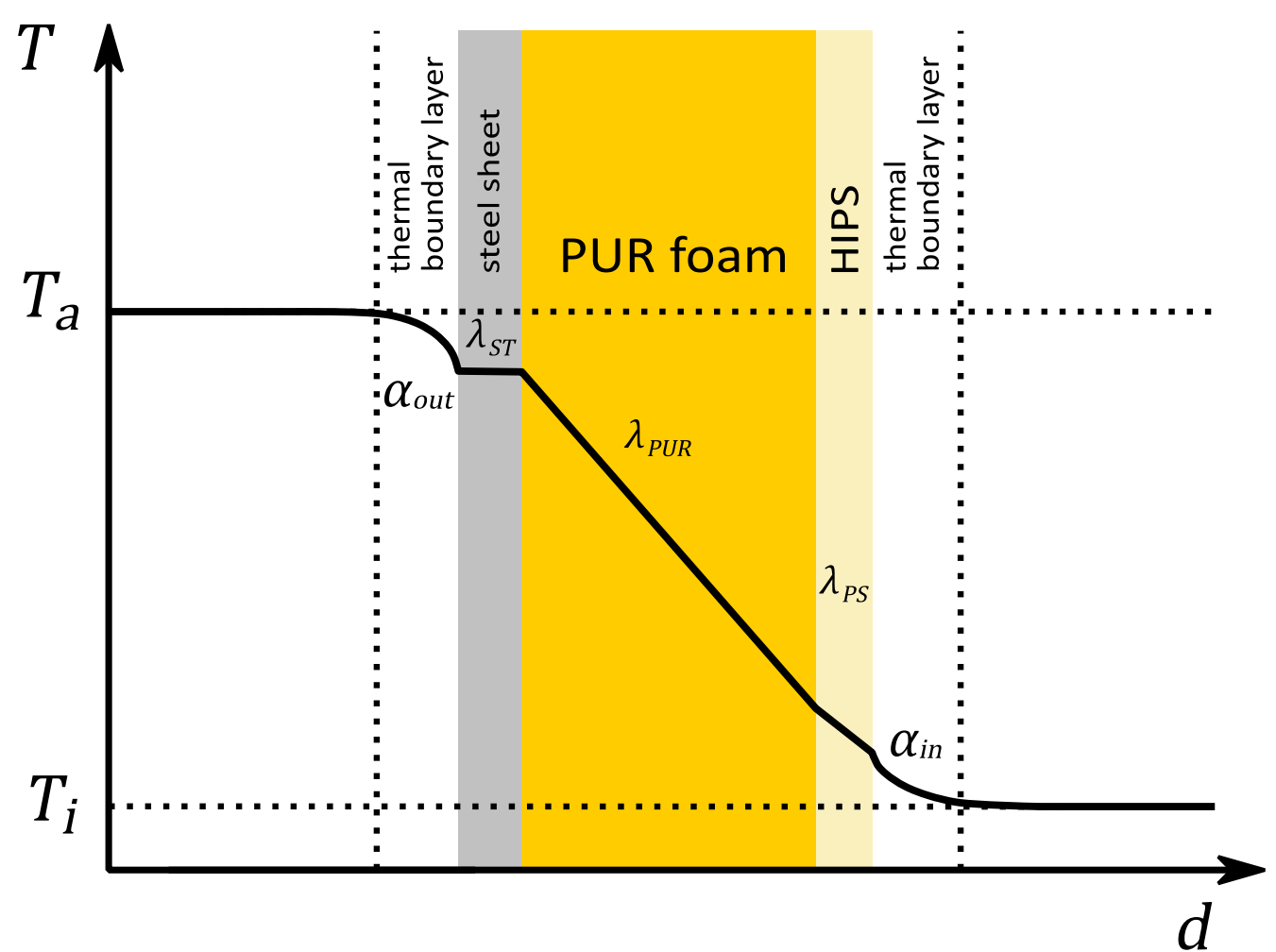

Fig. 1 Schematic of the cabinet wall structure of a household refrigerating appliance with a qualitative temperature profile.

\subsection{Measurement methods for the $k \cdot A$ value}

Several measurement methods to determine the heat flow through the refrigerating appliance cabinet walls have been proposed. Among them, the reverse heat leak method should be mentioned in particular. Various authors have reported on their investigations, modifications and improvements of the reverse heat leak method [24-28], which is also used in R\&D departments of refrigerating appliance manufacturers.

In contrast to the usual temperature conditions in the storage room of a refrigerating appliance, heat is supplied to the interior of the cabinet by means of an electric heater, while the ambient temperature is reduced, so that a heat flow occurs from the inside out. The electrical heating power needed to maintain a stable temperature inside the cabinet is directly related to the heat flow through the cabinet walls.

However, in practice, there are several problems with this experimental setup:

- Using the reverse heat leak method repeatedly over a period of several years can lead to accelerated aging, as cell gas diffusion is temperature dependent and progresses more rapidly at elevated temperatures.

- In order to prevent temperature stratification in the interior, fans are used in the reverse heat leak method to achieve a more homogeneous temperature distribution. However, the fans create a forced air flow that differs from natural convection in real household use. This results in a larger convective heat transfer coefficient and the ageing-dependent thermal conductivity of the PUR foam can be falsified. 
- Furthermore, the temperature difference between the storage room and the ambient differs from real household use, where the largest temperature difference occurs at the lower part of the storage room of the refrigerator, while the largest temperature difference is at the upper part of the storage room when the reverse heat leak method is used.

Conventional application:

$$
\begin{aligned}
& T_{m}=5^{\circ} \mathrm{C} \\
& T_{a}=25^{\circ} \mathrm{C}
\end{aligned}
$$
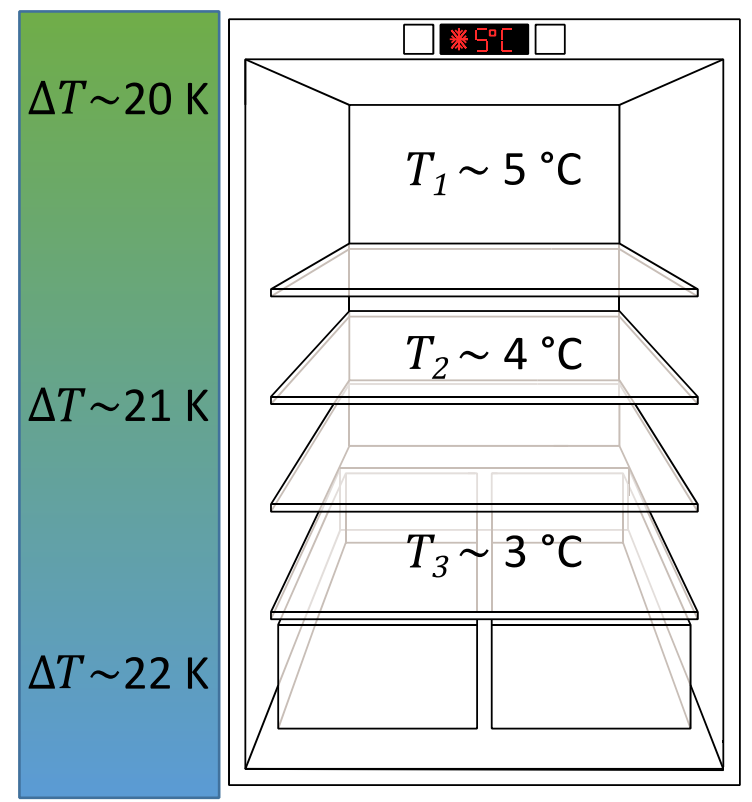

Reverse heat leak method:

$$
\begin{aligned}
& T_{m}=25^{\circ} \mathrm{C} \\
& T_{a}=5{ }^{\circ} \mathrm{C}
\end{aligned}
$$

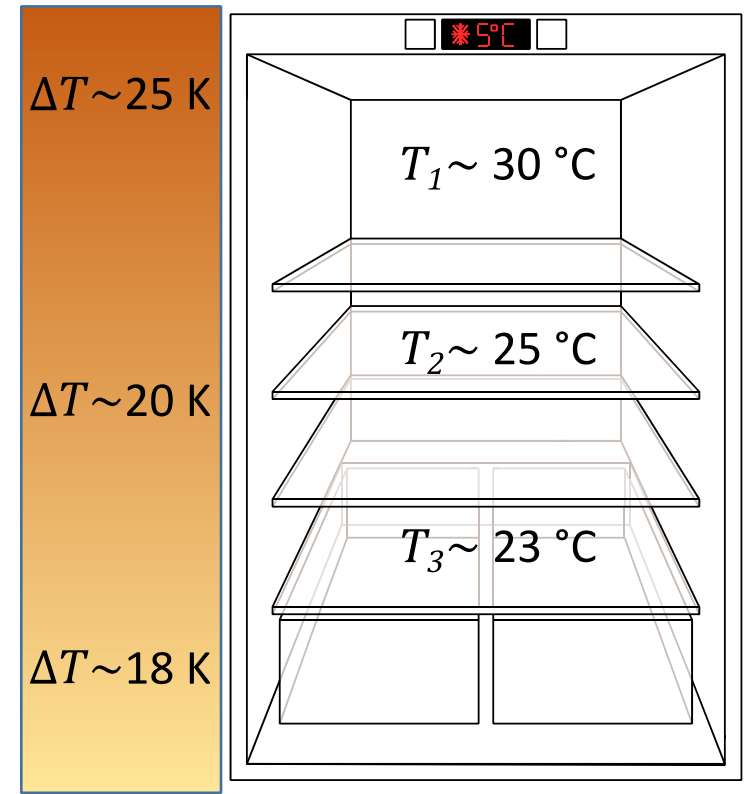

Fig. 2 Representation of the temperature gradient over a fresh food compartment during conventional use and reverse heat leak method measurement.

The heat flow can also be determined with heat flow sensors which are selectively placed on the cabinet. The functionality of the heat flow sensors was described by Lassue et al. [29]. Melo et al. investigated the use of heat flow sensors and compared the results with the reverse heat leak method [25]. This measuring method was further refined by Thiessen et al. [30].

However, the heat flow sensor measurement method also turned out to be unsuitable for the present project. Each refrigerating appliance has an individual cabinet design, depending on the manufacturer, brand, appliance type and condenser position arrangement. Cables and refrigerant pipes, which run through the PUR foam at various places, would have a strong impact on the results of this method.

Hueppe et al. [31] developed another measurement method. They determined the $k \cdot A$ value through the duration of a temperature rise in the storage compartments with a temperature rise test. In addition, aging tests on PUR foam samples have been published and show an increase of thermal conductivity of the PUR foam from $19.5 \mathrm{~mW} /(\mathrm{m} \mathrm{K})$ to $22.5 \mathrm{~mW} /(\mathrm{m} \mathrm{K})$ in 420 days. 
A non-destructive measuring method for the $k \cdot A$ value was developed in this work with the following aims:

The natural temperature stratification in the storage room of the refrigerating appliances and the temperature differences between the storage room and the ambient should be maintained as far as possible, natural convection should prevail in the storage room of the appliances and the measurement method should be integratable into the existing measurement setup of the standard energy consumption test according to the standard series IEC 62552:2015 (part 1-part 3) with as little effort as possible [32-34].

\section{$2.1 \quad$ Methodology}

In the present latent heat sink measuring method, the refrigeration cycle of the appliance does not operate. Instead, the storage room of the appliance is cooled by a heat sink in the form of an ice water bucket (height $210 \mathrm{~mm}$, diameter $254 \mathrm{~mm}$ ) with a volume of 10.64 liters, cf. Figures 3 and 4. To achieve a homogeneous temperature distribution of the entire bucket surface, several cooling fins were attached to the lid, which protruded into the ice water. To avoid temperature stratification in the ice water, a pump was installed at the bottom of the tank to enforce circulation. The electrical power consumed by the pump was measured and taken into account in the energy balance for the calculation of the $k \cdot A$ value. To monitor the melting process of the ice water, four thermocouples were attached to the container, which protruded into the ice water at two different heights. Furthermore, surface temperatures of the tank were measured with two thermocouples and that of the lid with a third thermocouple.
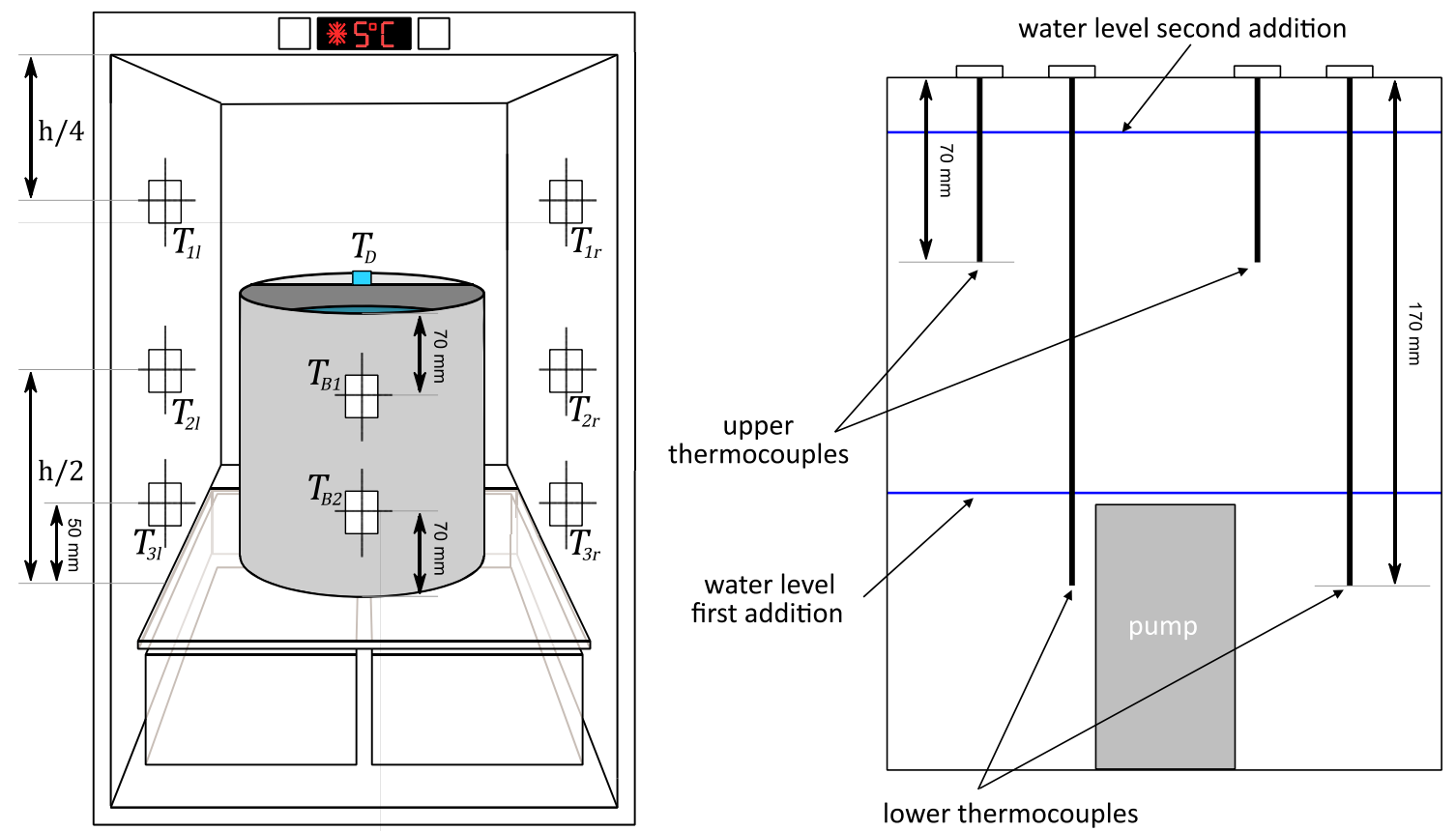

Fig. 3 Basic measurement setup in the fresh food compartment (left) and in the ice water bucket (right). 

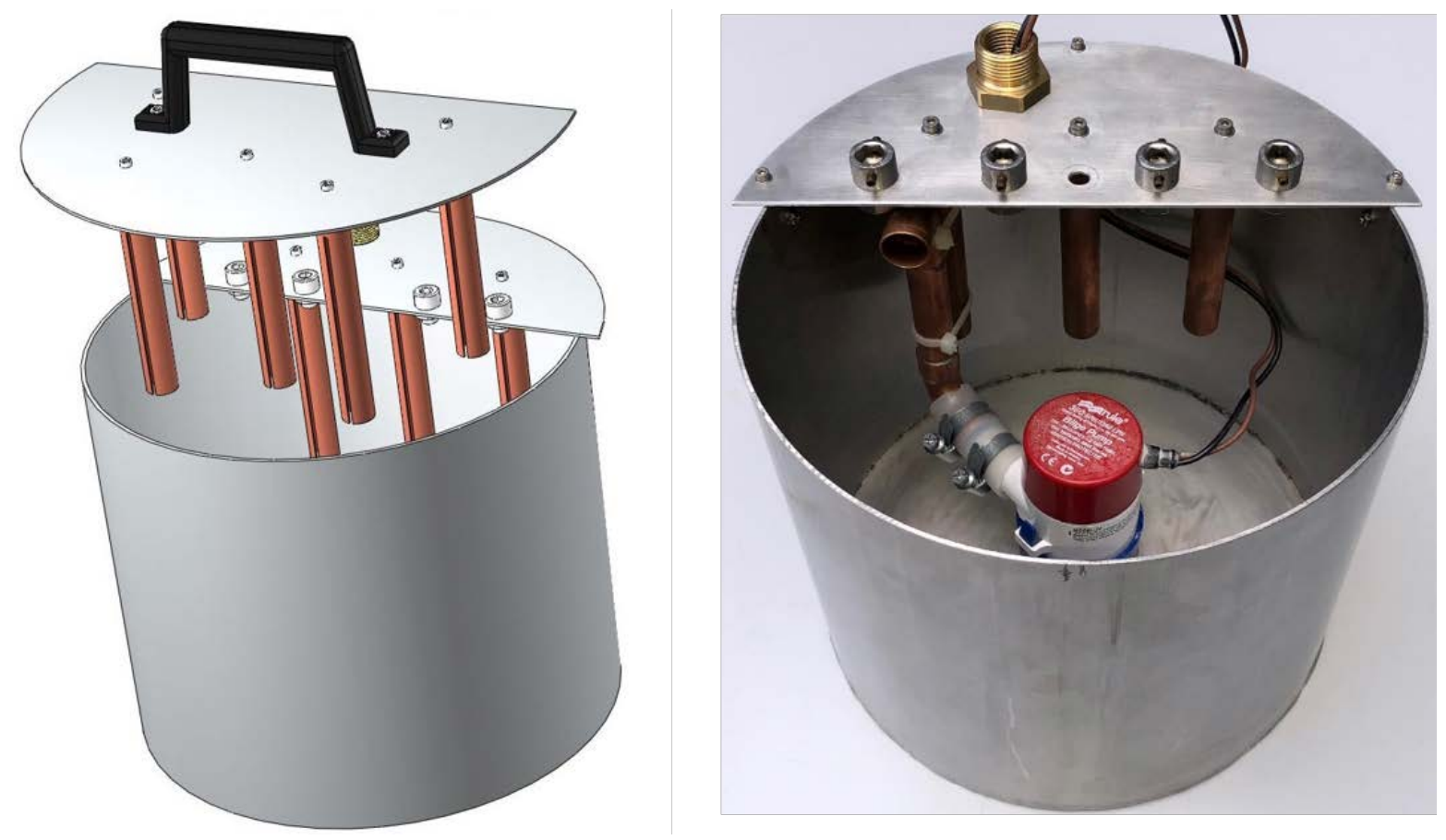

Fig. 4 Ice water bucket: technical drawing (left) and photo of the device (right).

Before the actual start of the experiment, the refrigerating appliance was operating at a time averaged fresh food compartment temperature of $T_{m a}=4{ }^{\circ} \mathrm{C}$ to $5^{\circ} \mathrm{C}$, which was determined as the mean value of the six temperature measuring points $\left(T_{1 l}\right.$ to $T_{3 l}$ and $T_{1 r}$ to $T_{3 r}$ ) located on both sides of the ice water bucket, cf. Figure 3. The measurements were made at ambient temperatures of $16{ }^{\circ} \mathrm{C}, 25^{\circ} \mathrm{C}$ and $32{ }^{\circ} \mathrm{C}$ following the IEC 62552:2015 series of standards (part 1 and 3) [32, 34]. Depending on the ambient temperature, the ice water bucket was filled with an amount of liquid water as shown in Table 1 at the start of each measurement.

In principle, the experiment should measure the time required for the ice melting process, where the water temperature remains constant. The point in time at which there is no longer a temperature of $0^{\circ} \mathrm{C}$ at all measuring points in the ice water can be seen as an increase in the temperature curve, cf. Figure 5. However, since there may still be residual ice in the bucket at this point in time, a solution had to be found to ensure that the amount of residual ice is the same at the start and the end of the measurement period. For this purpose, two ice additions were made.

First, a smaller amount of ice was added to the ice bucket. A relatively constant time period for the first melting phase could be achieved by varying this ice amount depending on the various ambient temperatures (cf. Table 1). During this phase in the experiment, the water level in the bucket only reaches the lower thermocouples, cf. Figure 3. 
Table 1 - Comparison of the test parameters of the first ice addition under different ambient temperatures.

\begin{tabular}{lccc} 
Ambient temperature & $16{ }^{\circ} \mathrm{C}$ & $25{ }^{\circ} \mathrm{C}$ & $32{ }^{\circ} \mathrm{C}$ \\
\hline Mass of liquid water in the ice water bucket & $4000 \pm 20 \mathrm{~g}$ & $3500 \pm 20 \mathrm{~g}$ & $3000 \pm 20 \mathrm{~g}$ \\
Mass of the first addition of ice & $1000 \pm 20 \mathrm{~g}$ & $1500 \pm 20 \mathrm{~g}$ & $2000 \pm 20 \mathrm{~g}$ \\
Time of the first melting phase & $7.00-7.75 \mathrm{~h}$ & $6.75-7.50 \mathrm{~h}$ & $7.00-7.75 \mathrm{~h}$ \\
\hline
\end{tabular}

When the lower thermocouples indicated that the temperature of the ice water had risen by $0.2 \mathrm{~K}$, a second quantity of ice was added to the bucket and the actual measurement was initiated. The evaluation period ended when the average temperature of all ice water thermocouples again rose by $0.2 \mathrm{~K}$. The evaluation period was thus the melting time $\left(\Delta \tau_{m}\right)$. Figure 5 shows the temperature profile of the ice water over the course of a measurement.

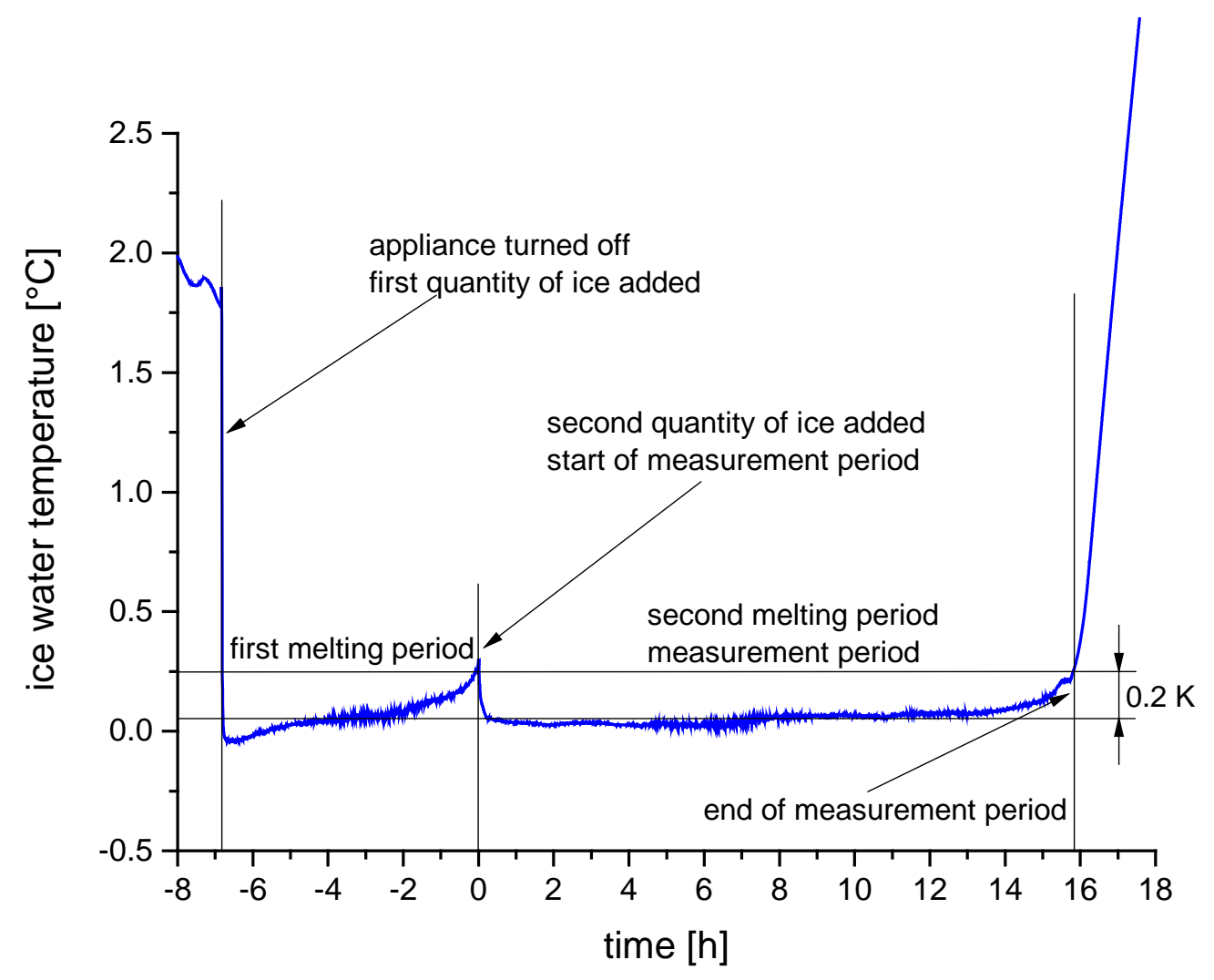

Fig. 5 Ice water temperature over time.

Validation tests were performed with a mass of $3500 \mathrm{~g}$ ice for the second addition and the measurements of the aging studies were performed with $3000 \mathrm{~g}$ to avoid overly long total measurement times. 


\subsection{Evaluation}

By determining the time interval that the ice needs to melt $\left(\Delta \tau_{m}\right)$, employing the enthalpy of fusion of water $\left(\Delta h_{m}=333.5 \mathrm{~kJ} / \mathrm{kg}\right)$ and the mass of ice at the second ice addition $\left(m_{i c e}\right)$, the heat flow $\left(\dot{Q}_{i c e}\right)$ is given by equation 3 . Since the ice was stored at temperatures below $0{ }^{\circ} \mathrm{C}\left(T_{i c e, 1}\right)$, the according enthalpy contribution was taken into account via the isochoric heat capacity of the ice $\left(c_{v, i c e}=2.204 \mathrm{~kJ} /(\mathrm{kg} \mathrm{K})\right)$. The electrical power of the pump $\left(P_{\text {pump }}\right)$ is dissipated by the circulation of the ice water and was considered in the energy balance.

$$
(k \cdot A)_{\text {total }}=\frac{m_{\text {ice }} \cdot\left(\Delta h_{m}+c_{v, i c e} \cdot\left(T_{i c e}-T_{i c e, 1}\right)\right)}{\left(T_{a}-T_{i c e}\right) \cdot \Delta \tau_{m}}-\frac{P_{\text {pump }}}{\left(T_{a}-T_{i c e}\right)}
$$

The equations presented in this way describe the $(k \cdot A)_{\text {total }}$ value for the heat flow entering the ice water through the appliance cabinet and the storage room. As shown in Figure 6, almost constant instantaneous temperatures $\left(T_{m a}\right)$ were present in the storage room of the fresh food compartment during the tests. The balance between the heat flows $\dot{Q}_{c a b}$ and $\dot{Q}_{i c e}$ remained practically constant until the end of the second melting phase. During the first melting phase, there was an increase of the instantaneous temperatures until a balance between the heat flow entering the storage room through the cabinet and the heat flow entering the ice water bucket from the storage room was established. The slightly lower instantaneous temperatures during the second melting phase can be explained by the higher degree of filling in the ice water bucket and the resulting larger surface of the bucket wetted by ice water.

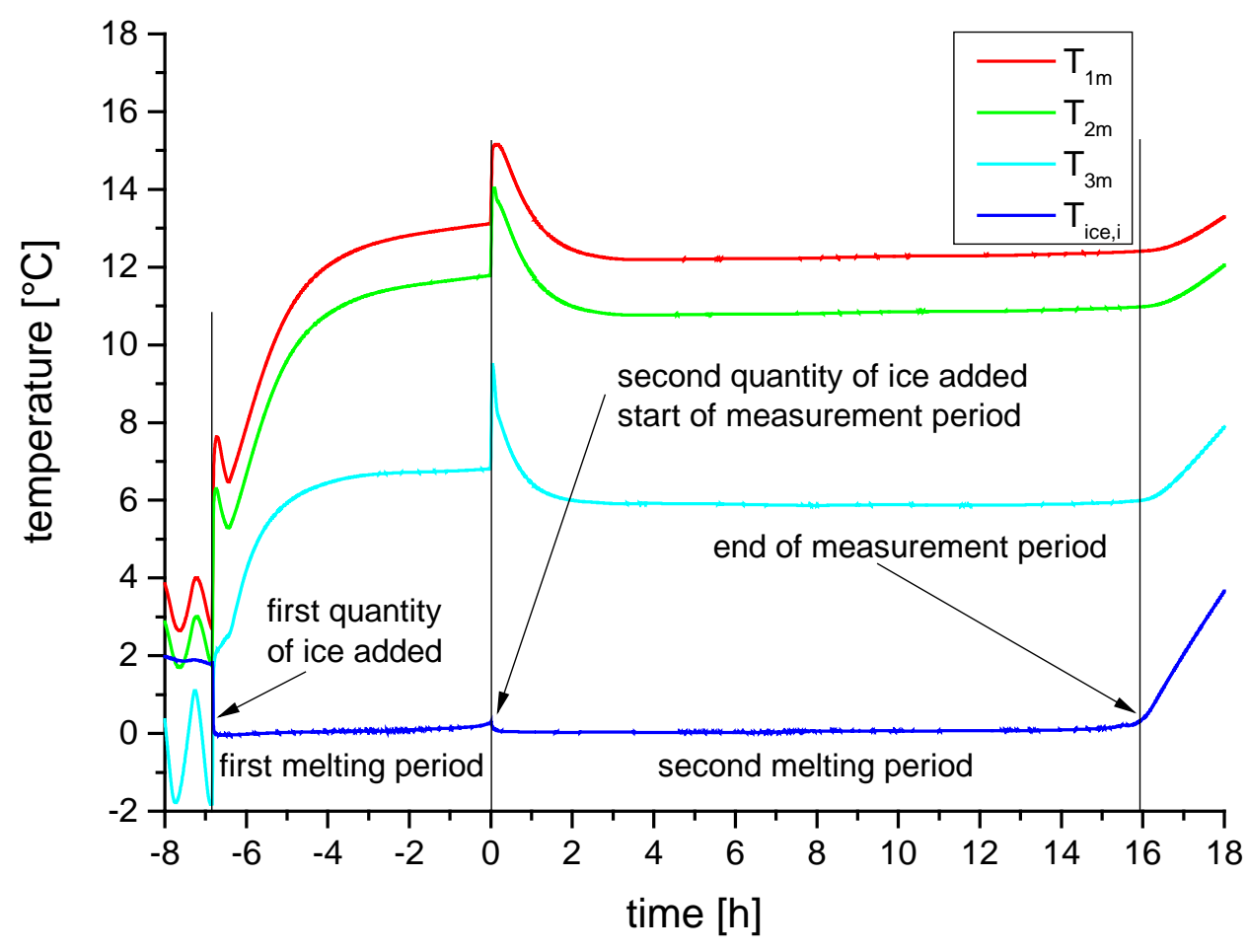

Fig. 6 Temperature at the measuring points in the fresh food compartment over time. 
Constant instantaneous temperatures in the fresh food compartment allow for the replacement of the ice water temperature with the instantaneous temperature of the fresh food compartment in equation 3 so that the $(k \cdot A)_{f f c}$ value related to the refrigerating appliance cabinet can be determined (cf. equation 4). For this purpose, the ice water temperature in the denominator is replaced with the average fresh food compartment temperature.

$$
(k \cdot A)_{f f c}=\frac{m_{i c e} \cdot\left(\Delta h_{m}+c_{v, i c e} \cdot\left(T_{i c e}-T_{i c e, 1}\right)\right)}{\left(T_{a}-T_{m a}\right) \cdot \Delta \tau_{m}}-\frac{P_{p u m p}}{\left(T_{a}-T_{m a}\right)}
$$

\subsection{Refrigerating appliances}

For a validation of the present measurement method, a commercially available tableheight refrigerator (Miele, type K12020 S-1) was used. This appliance (V1) was chosen due to its age of five years. The investigations discussed in section 1 show that the most pronounced aging effects occur in the first three years [10, 18-23]. Thus, only small changes of the $k \cdot A$ value were expected for this appliance. In addition, aging tests were carried out for four refrigerators (R1 to R4), cf. Table 2. Contrary to the requirements of the standard IEC 62552-1:2015, part1, [32] the built-in refrigerators were operated without wooden cabinets in order to exclude any influences of the wood on the measurement results. 


\begin{tabular}{|c|c|c|c|c|c|c|c|}
\hline Test device & & V1 & V2 & $\mathrm{R} 1$ & R2 & R3 & R4 \\
\hline $\begin{array}{l}\text { Refrigerator } \\
\text { model }\end{array}$ & & $\begin{array}{l}\mathrm{K} 12020 \\
\mathrm{~S}-1\end{array}$ & $\begin{array}{l}\text { KI81RAD } \\
30 / 04\end{array}$ & $\begin{array}{l}\text { KS 16-1 } \\
\text { RVA+++ }\end{array}$ & $\begin{array}{l}\text { KS 16-1 } \\
\text { RVA+++ }\end{array}$ & $\begin{array}{l}\text { KI81RAD } \\
30 / 04\end{array}$ & $\begin{array}{l}\text { KI81RAD } \\
30 / 04\end{array}$ \\
\hline Manufacturer & & Miele & Siemens & Exquisit & Exquisit & Siemens & Siemens \\
\hline $\begin{array}{l}\text { Refrigerator } \\
\text { type }\end{array}$ & & $\begin{array}{c}\text { table- } \\
\text { height } \\
\text { refrigerator }\end{array}$ & $\begin{array}{l}\text { built-in } \\
\text { refrigerator }\end{array}$ & $\begin{array}{c}\text { table- } \\
\text { height } \\
\text { refrigerator }\end{array}$ & $\begin{array}{c}\text { table- } \\
\text { height } \\
\text { refrigerator }\end{array}$ & $\begin{array}{l}\text { built-in } \\
\text { refrigerator }\end{array}$ & $\begin{array}{l}\text { built-in } \\
\text { refrigerator }\end{array}$ \\
\hline $\begin{array}{l}\text { Dimensions } \\
(H \times W \times D)\end{array}$ & [mm] & $\begin{array}{c}850 \times 601 \\
\times 628\end{array}$ & $\begin{array}{c}1775 \times 560 \\
\times 550\end{array}$ & $\begin{array}{l}845 \times 555 \\
\times 575\end{array}$ & $\begin{array}{l}845 \times 555 \\
\times 575\end{array}$ & $\begin{array}{c}1775 \times 560 \\
\times 550\end{array}$ & $\begin{array}{c}1775 \times 560 \\
\times 550\end{array}$ \\
\hline $\begin{array}{l}\text { Total storage } \\
\text { volume }\end{array}$ & [l] & 167 & 319 & 134 & 134 & 319 & 319 \\
\hline Refrigerant & & $\begin{array}{c}22 \mathrm{~g} \\
\mathrm{R} 600 \mathrm{a}\end{array}$ & $\begin{array}{c}46 \mathrm{~g} \\
\mathrm{R} 600 \mathrm{a}\end{array}$ & $\begin{array}{c}26 \mathrm{~g} \\
\mathrm{R} 600 \mathrm{a}\end{array}$ & $\begin{array}{c}26 \mathrm{~g} \\
\mathrm{R} 600 \mathrm{a}\end{array}$ & $\begin{array}{c}46 \mathrm{~g} \\
\mathrm{R} 600 \mathrm{a}\end{array}$ & $\begin{array}{c}46 \mathrm{~g} \\
\mathrm{R} 600 \mathrm{a}\end{array}$ \\
\hline Energy label & & $A+$ & $\mathrm{A}++$ & A+++ & A+++ & A++ & A++ \\
\hline
\end{tabular}

\subsection{Measurement system and measurement error analysis}

The mass of water and ice was measured with a laboratory scale DE350.5D (Kern \& Sohn $\mathrm{GmbH}$ ) with an accuracy of $\pm 2.5 \mathrm{~g}$. Temperatures were sampled by thermocouple differential measurements, where each measuring point had its own reference junction in a separate ice water bath. The measurement signal of the thermocouples was processed by a combination of a pre-amplifier LTC1050 (Linear Technologies) with adjusted gain of 1000 and a digital-to-analog converter system OMB-DAQ 55/56 (Omega Technologies), limiting the offset drift to $\pm 0.025 \mathrm{~K}$. By calibrating each thermocouple individually and applying a polynomial correction, the measurement error was reduced from $\pm 1 \% \times \Delta T$ to $\pm 0.5 \% \times \Delta T$. All measurements were carried out in a climatic chamber with an ambient temperature fluctuation of $\pm 0.5 \mathrm{~K}$ and an air humidity of $50 \%$. The supply voltage of the pumps was provided by BT-305 laboratory power supplies (BASETech) with $\pm 1 \%+0.02 \mathrm{~V}$ accuracy and the electric current with $\pm 2 \%+0.02 \mathrm{~A}$. Due to cable length, the supply voltage at the pump was $1 \%$ lower than the output of the power supply, which was taken into account in the calculations. The pumps (Bilge pump 360GPH) were operated with a supply voltage of $5 \mathrm{~V}$. In preliminary tests, this turned out to be the best compromise between the heat introduced by the pump and the necessary circulation of the ice water to prevent temperature stratification in the bucket.

The measurement errors of the various devices are summarized in Table 3. The fluctuation of the ice storage temperature $\left(T_{i c e, 1}\right)$ was assumed to be $\pm 1 \mathrm{~K}$ due to transportation and handling of the ice prior to the addition process. The measurement errors $\Delta(k \cdot A)_{\text {total }}$ and $\Delta(k \cdot A)_{f f c}$ were calculated with the error propagation law. 
Table 3 - Measured properties and their uncertainties.

\begin{tabular}{lcc} 
Measured quantity & Measuring device & Uncertainty \\
\hline Temperature & Thermocouples & $\pm 0.1 \mathrm{~K}$ \\
Voltage & Laboratory power supplies & $\pm 1 \%+0.02 \mathrm{~V}$ \\
Electric current & Laboratory power supplies & $\pm 2 \%+0.02 \mathrm{~A}$ \\
Time & Personal computer & \pm 0.1 s/day \\
Mass & Laboratory scale & $\pm 2.5 \mathrm{~g}$ \\
\hline
\end{tabular}

\section{Results and discussion}

\subsection{Validation}

For validation, five measurements for each ambient temperature of $16{ }^{\circ} \mathrm{C}, 25^{\circ} \mathrm{C}$ and $32{ }^{\circ} \mathrm{C}$ were carried out with refrigerating appliance V1. The aim was to check the reproducibility and the influence of the ambient temperature on the results. In addition to the measured values and the results for the $k \cdot A$ values of the individual measurements, the total measurement errors $\Delta(k \cdot A)_{\text {total }}$ and $\Delta(k \cdot A)_{f f c}$ are specified in the following.

Overall, the data show a homogeneous distribution of the measurement results with a scatter on the same order of magnitude as the overall measurement error. As shown in Table 4, no influence of the ambient temperature on the measurement results was found.

\section{Table 4 - Results of the validation test series with varying ambient} temperature.

\begin{tabular}{lccrrr}
\hline Test series & & & $16{ }^{\circ} \mathrm{C}$ & $25{ }^{\circ} \mathrm{C}$ & $32{ }^{\circ} \mathrm{C}$ \\
\hline Ambient temperature & $T_{a}$ & {$\left[{ }^{\circ} \mathrm{C}\right]$} & 15.7 & 24.8 & 31.8 \\
\hline Mass of the second addition of ice & $m_{\text {ice }}$ & {$[\mathrm{g}]$} & 3489.0 & 3490.5 & 3493.5 \\
\hline Evaluation period & $\Delta \tau_{m}$ & {$[\mathrm{~h}]$} & 22.81 & 15.83 & 12.90 \\
\hline $\begin{array}{l}\text { Average fresh food compartment } \\
\text { temperatures }\end{array}$ & $T_{m *}$ & {$\left[{ }^{\circ} \mathrm{C}\right]$} & 6.3 & 9.8 & 12.8 \\
\hline Power of the pump & $P_{\text {pump }}$ & {$[\mathrm{W}]$} & 4.35 & 4.35 & 4.29 \\
\hline$(k \cdot A)_{\text {total }}$ & & {$[\mathrm{W} / \mathrm{K}]$} & 0.74 & 0.75 & 0.75 \\
\hline$\Delta(k \cdot A)_{\text {total }}$ & & {$[\%]$} & $1.9 \%$ & $1.2 \%$ & $0.9 \%$ \\
\hline$(k \cdot A)_{f f c}$ & & {$[\mathrm{~W} / \mathrm{K}]$} & 1.22 & 1.24 & 1.25 \\
\hline$\Delta(k \cdot A)_{f f c}$ & & {$[\%]$} & $1.3 \%$ & $0.8 \%$ & $0.6 \%$ \\
\hline
\end{tabular}

Despite the relatively constant results at different ambient temperatures, an ambient temperature of $25^{\circ} \mathrm{C}$ was preferred for this measurement method. At an ambient temperature of $16{ }^{\circ} \mathrm{C}$ there are significantly higher measurement errors $( \pm 1.9 \%)$ and a time of more than $24 \mathrm{~h}$ for an entire test (first and second addition of ice) leads to additional organizational effort in labor operation. In addition, only for this ambient temperature, it was observed that an ice layer formed in the bucket on the water 
surface. A comparison of the ambient temperatures of $25{ }^{\circ} \mathrm{C}$ and $32{ }^{\circ} \mathrm{C}$ shows that the measurement error is lower at $32^{\circ} \mathrm{C}$, but the internal temperatures were significantly higher than in regular refrigerator operation. Table 5 shows the selection criteria mentioned for the evaluation of the three ambient temperatures.

\section{Table 5 - Evaluation for the selection of the ambient temperature.}

\begin{tabular}{lcccc} 
Ambient temperature & $\Delta(k \cdot A)_{\max }$ & $16{ }^{\circ} \mathrm{C}$ & $25{ }^{\circ} \mathrm{C}$ & $32{ }^{\circ} \mathrm{C}$ \\
\hline \multirow{2}{*}{ Measurement error } & second melting interval $\left(\Delta \tau_{m}\right)$ & $22.80 \mathrm{~h}$ & $15.63 \mathrm{~h}$ & $12.90 \mathrm{~h}$ \\
\cline { 2 - 5 } & total & $30.50 \mathrm{~h}$ & $23.00 \mathrm{~h}$ & $20.50 \mathrm{~h}$ \\
\cline { 2 - 5 } & & - & 0 & + \\
\hline \multirow{2}{*}{\begin{tabular}{l} 
Ice layer on the water surface \\
\cline { 2 - 5 }
\end{tabular}} & & yes & no & no \\
\hline $\begin{array}{l}\text { Average fresh food } \\
\text { compartment } \\
\text { temperature }\end{array}$ & $T_{m *}$ & -- & + & + \\
\hline
\end{tabular}

\section{2 $\quad$ Aging studies}

With the present measuring method, the aging of commercially available refrigerating appliances was investigated shortly after their manufacturing. For this purpose, two tests per appliance were carried out on four appliances at an interval of 14 months and the $k \cdot A$ value was determined. The results are listed in Table 6. Figure 7 shows the results for the $(k \cdot A)_{\text {total }}$ value and the $(k \cdot A)_{f f c}$ value. The results indicate an increase between $3.6 \%$ and $11.5 \%$ for $(k \cdot A)_{\text {total }}$ and an increase between $6.1 \%$ and $11.3 \%$ for $(k \cdot A)_{f f c}$. This difference between the $k \cdot A$ values is significantly larger than the measurement error $\left(\Delta(k \cdot A)_{\max }<2 \%\right)$. Hueppe et al. [31] investigated the change of the thermal conductivity of PUR foam samples over time and observed an increase of about $15 \%$ over a period of 420 days. The determined increase of the $k \cdot A$ value of real refrigerating appliances is of similar magnitude. 


\section{Table 6 - Results of the aging study of refrigerating appliances.}

\begin{tabular}{|c|c|c|c|c|c|c|}
\hline \multicolumn{3}{|l|}{ Test device } & R1 & $\mathrm{R} 2$ & R3 & R4 \\
\hline \multicolumn{3}{|c|}{ Refrigerator model } & $\begin{array}{l}\text { KS 16-1 } \\
\text { RVA+++ }\end{array}$ & $\begin{array}{l}\text { KS 16-1 } \\
\text { RVA+++ }\end{array}$ & $\begin{array}{c}\text { KI81RAD } \\
30 / 04\end{array}$ & $\begin{array}{c}\text { KI81RAD } \\
30 / 04\end{array}$ \\
\hline \multicolumn{3}{|c|}{ Manufacturer } & Exquisit & Exquisit & Siemens & Siemens \\
\hline \multirow{4}{*}{$(k \cdot A)_{\text {total }}$} & new & {$[\mathrm{W} / \mathrm{K}]$} & 0.56 & 0.53 & 0.82 & 0.78 \\
\hline & after 14 months & {$[\mathrm{W} / \mathrm{K}]$} & 0.58 & 0.58 & 0.88 & 0.87 \\
\hline & difference & {$[\mathrm{W} / \mathrm{K}]$} & +0.02 & +0.05 & +0.06 & +0.09 \\
\hline & & [\%] & $+3.6 \%$ & $+9.4 \%$ & $+7.3 \%$ & $+11.5 \%$ \\
\hline \multirow{4}{*}{$(k \cdot A)_{f f c}$} & new & {$[\mathrm{W} / \mathrm{K}]$} & 0.82 & 0.78 & 1.65 & 1.60 \\
\hline & after 14 months & {$[\mathrm{W} / \mathrm{K}]$} & 0.87 & 0.86 & 1.79 & 1.78 \\
\hline & difference & {$[\mathrm{W} / \mathrm{K}]$} & +0.05 & +0.08 & +0.14 & +0.18 \\
\hline & & [\%] & $+6.1 \%$ & $+10.3 \%$ & $+8.5 \%$ & $+11.3 \%$ \\
\hline
\end{tabular}

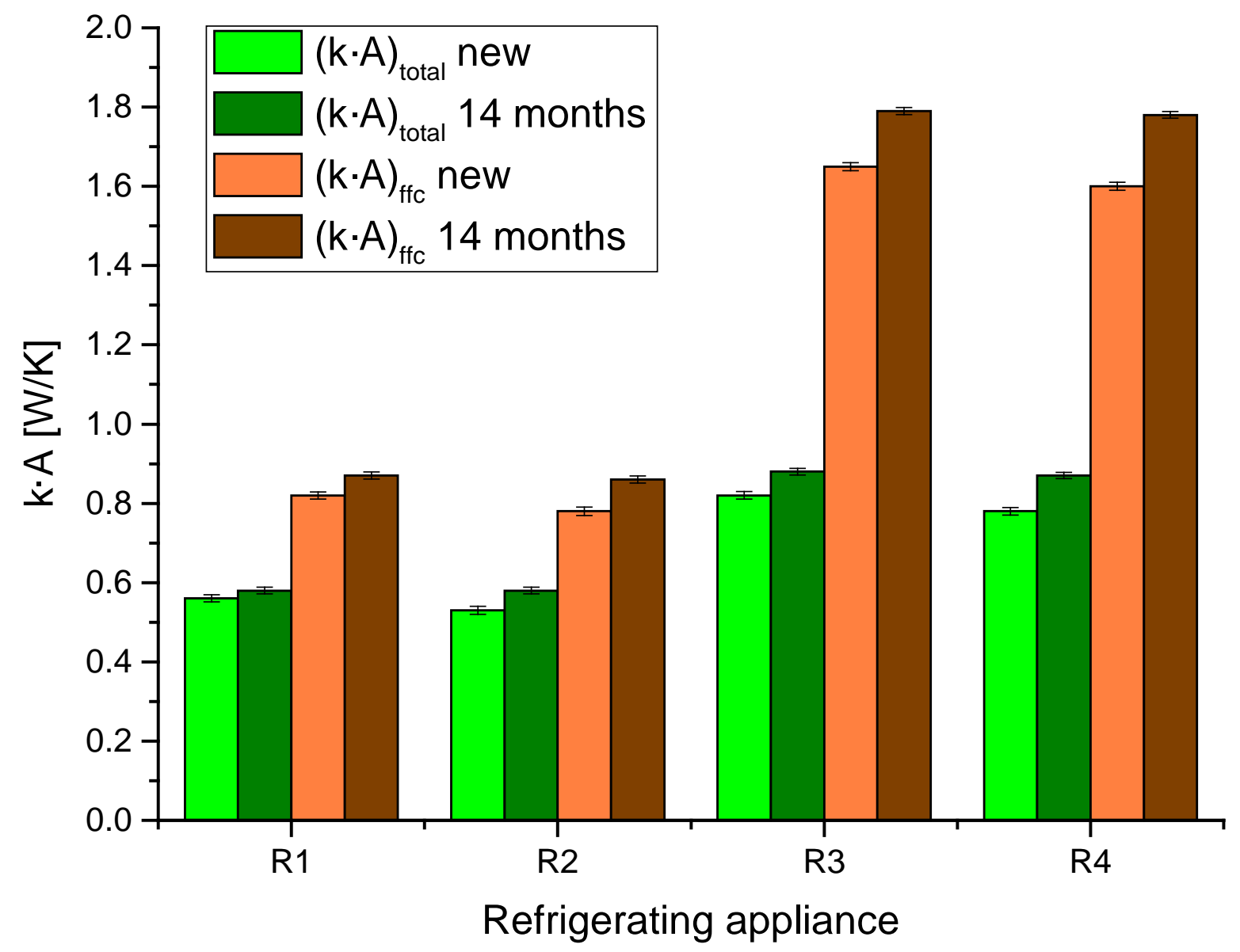

Fig. 7 Results of the aging study for $(\boldsymbol{k} \cdot \boldsymbol{A})_{t o t a l}$ (green) and $(\boldsymbol{k} \cdot \boldsymbol{A})_{f f c}$ (brown). 


\section{$4 \quad$ Conclusions}

The presented experimental method with a latent heat sink is a suitable alternative to the reverse heat leak method for determining the heat flow into the cabinet of a refrigerating appliance. The advantage of the latent heat sink method is that the air flow and the temperatures in the storage room are comparable to the real operating conditions. The usage of fans in the reverse heat leak method generates locally turbulent flows, which increase convective heat transfer. The temperature gradient between the storage room and the ambient is also more realistic.

An ambient temperature of $25^{\circ} \mathrm{C}$ was found to be optimal for using the latent heat sink method. Application-related temperatures are reached in the storage compartments, the measurement error is small and the total measurement time can be integrated into a $24 \mathrm{~h}$ cycle. An ambient temperature of $32{ }^{\circ} \mathrm{C}$ should not be chosen due to the higher storage temperature in the compartment and $16{ }^{\circ} \mathrm{C}$ should not be chosen due to the possible formation of ice layers.

By measuring the $k \cdot A$ value of new refrigerating appliances over time, an increase of $8.2 \%( \pm 2.1 \%)$ for the table high refrigerators and $9.9 \%( \pm 1.4 \%)$ for the large built-in refrigerators was found over a period of 14 months. This result is consistent with the literature for the increase of the thermal conductivity of PUR foam.

\section{Acknowledgements}

This work was carried out as part of the ALGE research project funded by the German Federal Ministry for Economic Affairs and Energy as part of the 6th energy research program (project funding reference number: 03ET1544A-E). 


\section{References}

[1] Statista: Haushaltsgroßgeräte. 2018, URL: https://de.statista.com/statistik/studie/id/7683/dokument/haushaltsgrossgeraetestatista-dossier/.

[2] Australian Consumers' Association, 1990. Energy Consumption of Refrigerators and Freezers Used Under Normal Conditions of Use. Choice, Sydney, Australia.

[3] Kjeldsen, P., Jensen, M.H., 2001. Release of CFC-11 from Disposal of Polyurethane Foam Waste. Environmental Science \& Technology 35, 30553063.

[4] Scheutz, C., Kjeldsen, P., 2002. Determination of the fraction of blowing agent released from refrigerator/freezer foam after decommissioning the product. Environment and Resources DTU, Technical University of Denmark.

[5] Yazici, B., Can, Z.S., Calli, B., 2014. Prediction of future disposal of end-of-life refrigerators containing CFC-11. Waste Management 34, 162-166.

[6] Meyer, A, 1993. Der FCKW-freie Kuehlschrank der FORON-Hausgeraete gmbH - ein Beitrag fuer eine bessere Umwelt. Luft- und Kaeltetechnik 29, Nr. 1, 3-4.

[7] Stiftung Warentest, 1994. Umwelt geschont - Strom gespart. test 1994, Nr.3, 3639.

[8] Stiftung Warentest, 1994. Auch ohne Ozonkiller. test 1994, Nr.6, 24-25.

[9] Delebecq, E., Pascault, J.-P., Boutevin, B., Ganachaud, F., 2013. On the versatility of urethane/urea bonds: reversibility, blocked isocyanate, and nonisocyanate polyurethane. Chemical Reviews 2013113, 80-118.

[10] Elsner, A., Müller, M., Paul, A., Vrabec, J., 2013. Zunahme des Stromverbrauchs von Haushaltskältegeräten durch Alterung. Deutsche Kälte-Klima Tagung 40, Hannover, Germany, November 20-22, 2013.

[11] Harrington, L., 2017. Quantifying energy savings from replacement of old refrigerators. Energy Procedia 121, 49-56.

[12] Harrington, L., 2018. Prediction of the energy consumption of refrigerators during use. Dissertation, Melbourne (Australia): https://minervaaccess.unimelb.edu.au/handle/11343/213357

[13] Wagner, K-E., 2002. Simulation und Optimierung des Wärmedämmvermögens von PUR Hartschaum, Wärme- und Stofftransport sowie mechanische Verformung, Dissertation, Stuttgart (Germany): http://dx.doi.org/10.18419/opus$\underline{1579}$.

[14] 2010 ASHRAE Handbook: Refrigeration. SI edition. Atlanta, GA: ASHRAE, 2010. ISBN 1933742828. 
[15] Engels, H.-W., Pirkl, H.-G., Albers, R., Albach, R.W., Krause, J., Hoffmann, A., Casselmann, H., Dormish, J., 2013. Polyurethane: vielseitige Materialien und nachhaltige Problemlöser für aktuelle Anforderungen. Angewandte Chemie 125, 9596-9616.

[16] Tucker, B.W., 1992. Rigid polyurethane foams with low thermal conductivities, patent document, US005169877A, PCT, 08.12.1992.

[17] Berardi, U., Madzarevic, J., 2020. Microstructural analysis and blowing agent concentration in aged polyurethane and polyisocyanurate foams. Applied Thermal Engineering 164, 114440.

[18] Wilkes K.E., Yarbrough D.W., Weaver F.J., 1997. Aging of polyurethane foam insulation in simulated refrigerator walls. International Conference on Ozone Protection Technologies, Baltimore Maryland, November 12-13, 1997.

[19] Wilkes, K.E., Gabbard, W.A., Weaver, F.J., 1999. Aging of polyurethane foam insulation in simulated refrigerator panels: One-year results with third-generation blowing agents. The Earth Technologies Forum, Washington D.C., September 27-29, 1999.

[20] Wilkes, K.E., Gabbard, W.A., Weaver, F.J., Booth, J.R., 2001. Aging of polyurethane foam insulation in simulated refrigerator panels: Two-year results with third-generation blowing agents. Journal of Cellular Plastics 37, 400-428.

[21] Wilkes, K.E., Yarbrough, D.W., Gabbard, W.A., Nelson, G.E., Booth, J.R., 2002. Aging of polyurethane foam insulation in simulated refrigerator panels: Threeyear results with third-generation blowing agents. Journal of Cellular Plastics 38, 317-339.

[22] Wilkes, K.E., Yarbrough, D.W., Nelson, G.E., Booth, J.R., 2003. Aging of polyurethane foam insulation in simulated refrigerator panels: Four-year results with third-generation blowing agents. The Earth Technologies Forum, Washington D.C., April 22-24, 2003.

[23] Albrecht, W., 2003. Änderung der Wärmeleitfähigkeit von zehn Jahre alten PURHartschaumplatten mit gasdiffusionsoffenen Deckschichten. Bauphysik 25, 317319.

[24] Stovall, T., 2012. Closed Cell Foam Insulation: A review of long term thermal performance, Oak Ridge National Laboratory report ORNL/TM-2012/583.

[25] Melo, C., da Selva, L.W., Pereira, R.H., 2000. Experimental evaluation of the heat transfer through the walls of household refrigerators. Eighth International Refrigeration Conference at Purdue University, West Lafayette, IN, USA, July 2528, 2000, 353-360.

[26] Lieghton, D.L., 2011. Investigation of household refrigerator with alternative low global warming potential refrigerants. Master thesis, University of Maryland, USA. 
[27] Sim, J.S., Ha, J.S., 2011. Experimental study of heat transfer characteristics for a refrigerator by using reverse heat loss method. International Communications in Heat and Mass Transfer 38, 572-576.

[28] Hermes, C., Melo, C., Knabben. F., 2013. Alternative test method to assess the energy performance of frost-free refrigerating appliances. Applied Thermal Engineering 50, 1029-1034.

[29] Lassue, S., Guths, S., Leclercq, D., Duthoit, B., 1993. Contribution to the experimental study of natural convection by heat flux measurement an anemometry using thermoelectric effects. Experimental Heat Transfer, Fluid Mechanics and Thermodynamics 1993, 831-838.

[30] Thiessen, S., Knabben, F.T., Melop, C., 2014. Experimental evaluation of the heat fluxes through the walls of a domestic refrigerator. $15^{\text {th }}$ Brazilian Congress of Thermal Sciences an Engineering at Belem, PA, Brazil, November 10-13, 2014.

[31] Hueppe, C., Geppert, J., Stamminger, R., Wagner, H., Hoelscher, H., Vrabec, J., Paul, A., Elsner, A., Becker, W., Gries, U., Freiberger, A., 2020. Age-related efficiency loss of household refrigeration appliances: Development of an approach to measure the degradation of insulation properties. Applied Thermal Engineering 173, 115113.

[32] IEC 62552:2015, 2015. IEC 62552-1:2015 Household Refrigerating Appliances Characteristics and Test Methods - Part 1: General requirements. International Electrotechnical Commission (IEC).

[33] IEC 62552:2015, 2015. IEC 62552-2:2015 Household Refrigerating Appliances Characteristics and Test Methods - Part 2: Performance requirements. International Electrotechnical Commission (IEC).

[34] IEC 62552:2015, 2015. IEC 62552-3:2015 Household Refrigerating Appliances Characteristics and Test Methods - Part 3: Energy consumption and volumes. International Electrotechnical Commission (IEC). 